\title{
Homocysteine, a Thrombogenic Agent, Suppresses Anticoagulant Heparan Sulfate Expression in Cultured Porcine Aortic Endothelial Cells
}

\author{
Masanori Nishinaga, ${ }^{\star \star}$ Toshio Ozawa, ${ }^{\star}$ and Kazuyuki Shimada * \\ ${ }^{*}$ Department of Cardiology, Jichi Medical School, Kawachigun, Tochigi 329-04, Japan; and ${ }^{\ddagger}$ Department of Medicine and Geriatrics, \\ Kochi Medical School, Nankoku, Kochi 783, Japan
}

\begin{abstract}
Previous studies showed that homocysteine, a thromboatherogenic and atherogenic agent, inhibits an endothelial thrombomodulin-protein $C$ anticoagulant pathway. We examined whether homocysteine might affect another endothelial anticoagulant mechanism; i.e., heparin-like glycosamino-glycan-antithrombin III interactions. Incubations of porcine aortic endothelial cell cultures with homocysteine reduced the amount of antithrombin III bound to the cell surface in a dose- and timedependent fashion. The inhibitory effect was observed at a homocysteine concentration as low as $0.1 \mathrm{mM}$, and the maximal suppression occurred at $1 \mathrm{mM}$ of homocysteine after $24 \mathrm{~h}$. In contrast with a marked reduction in the maximal antithrombin III binding capacity ( $\sim 30 \%$ of control $)$, the radioactivity of $\left[{ }^{35} \mathrm{~S}\right]$ sulfate incorporated into heparan sulfate on the cell surface was minimally $(<15 \%)$ reduced. The cells remained viable after homocysteine treatment. Although neither net negative charge nor proportion in total glycosaminoglycans of cell surface heparan sulfate was altered by homocysteine treatment, a substantial reduction in antithrombin III binding capacity of heparan sulfate isolated from homocysteine-treated endothelial cells was found using both affinity chromatography and dot blot assay techniques. The antithrombin III binding activity of endothelial cells decreased after preincubation with $1 \mathrm{mM}$ homocysteine, cysteine, or 2-mercaptoethanol; no reduction in binding activity was observed after preincubation with the same concentration of methionine, alanine, or valine. This sulf hydryl effect may be caused by generation of hydrogen peroxide, as incubation of catalase, but not superoxide dismutase, with homocysteine-treated endothelial cells prevented this reduction, whereas copper augmented the inhibitory effects of the metabolite. Thus, our data suggest that the inhibited expression of anticoagulant heparan sulfate may contribute to the thrombogenic property resulting from the homocysteine-induced endothelial cell perturbation, mediated by generation of hydrogen peroxide through alteration of the redox potential. (J. Clin. Invest. 1993. 92:1381-1386.) Key words: arteriosclerosis • thrombosis - antithrombin III • proteoglycan • hydrogen peroxide
\end{abstract}

Address correspondence to Kazuyuki Shimada, M.D., Department of Cardiology, Jichi Medical School, 331 1-1 Minami-kawachimachi, Kawachigun, Tochigi 329-04, Japan.

Received for publication 31 December 1992 and in revised form 12 April 1992.

J. Clin. Invest.

(C) The American Society for Clinical Investigation, Inc.

0021-9738/93/09/1381/06 \$2.00

Volume 92, September 1993, 1381-1386

\section{Introduction}

Endothelial cells possess several antithrombotic mechanisms, including thrombomodulin-protein $\mathrm{C}$ and heparin-like glycosaminoglycan-antithrombin III anticoagulant pathways (1). Little is known, however, how these endothelial cell functions are regulated, and whether modulations of these functions could lead to thrombosis and/or vascular injury. The cytokines, potent immunologic and inflammatory mediators, have been shown to suppress anticoagulant activity through decreased cell surface thrombomodulin $(2,3)$ and heparin-like compounds on endothelial cells (4). These mechanisms may contribute to the thrombus formation and vasculopathy associated with inflammatory responses (5).

Homocysteinemia caused by homozygous cystathionine $\beta$-synthase deficiency is associated with an increased incidence of vascular thrombosis and development of arteriosclerosis (6). Furthermore, elevated plasma homocysteine levels have been reported to be an independent risk factor for vascular disease (7-10). The administration of homocysteine caused vascular injury and thrombosis in animals (11). The mechanisms by which homocysteinemia leads to thrombosis and arteriosclerosis has not been completely defined yet. Recent studies using cell culture systems have shown that homocysteine enhances endothelial cell-associated Factor V activity (12), and inhibits both thrombomodulin surface expression and protein $\mathrm{C}$ activation (13-15). Thus, endothelial cell coagulant properties were shown to be regulated by atherogenic stimuli. To our knowledge, however, no studies have yet reported the involvement of another important endothelial anticoagulant pathway; i.e., endothelial cell heparin-like glycosaminoglycans-antithrombin III anticoagulant mechanism, in this unique model of thrombosis and arteriosclerosis.

The present study was designed to determine whether an exposure of endothelial cells to homocysteine might affect the interactions of cells with antithrombin III, and if so, to determine the mechanism(s) by which homocysteine modulates this endothelial cell function.

\section{Methods}

Materials. RPMI 1640 medium, Dulbecco's phosphate-buffered saline, Hanks' balanced salt solution, and fetal calf serum were obtained from Grand Island Biological Co. (Grand Island, NY). Petri dishes ( 35 $\times 10 \mathrm{~mm}$ ) were products of Falcon Labware (Cockeysville, MD). Mono Q (HR5/5) was from Pharmacia Fine Chemicals (Uppsala, Sweden). Affi-Gel was purchased from Bio-Rad Laboratories (Richmond, CA). The solid-phase oxidizing agent, 1,3,4,6-tetrachloro$3 \alpha, 6 \alpha$-diphenyl glycoluril (Iodogen), was supplied by Pierce Chemical Co. (Rockford, IL). $\mathrm{Na}^{125} \mathrm{I}$ ( $3.64 \mathrm{GBq} / \mathrm{ml} \mathrm{NaOH}$ solution, $\mathrm{pH}$ 7-11) was purchased from Amersham Corp. (Arlington Heights, IL). $\left[{ }^{35} \mathrm{~S}\right]-$ 
sulfate (carrier free, $1.52 \mathrm{GBq} / \mathrm{ml}$ ) was obtained from the Japanese Atomic Energy Research Institute (Ibaragi, Japan). $\mathrm{Na}_{2}\left[{ }^{51} \mathrm{Cr}\right] \mathrm{O}_{4}(37$ $\mathrm{MBq} / \mathrm{ml}$ in saline, $\mathrm{pH} \mathrm{8-10)}$ was from New England Nuclear Corp. (Boston, MA). D,L-homocysteine, D,L-cysteine, D,L-methionine, and $\mathrm{L}-\alpha$-alanine were purchased from Nacalai Tesque Inc. (Kyoto, Japan). 2-Mercaptoethanol was obtained from Sigma Chemical Co., (St. Louis, MO). Catalase and superoxide dismutase from Seikagaku Kogyo (Tokyo, Japan). All other materials were reagent grade.

Endothelial cell cultures. Porcine aortic endothelial cells were cultured in gelatin-precoated 35-mm Petri dishes containing RPMI 1640 medium, supplemented with $10 \%$ fetal calf serum and antibiotics as previously described (16-18). Cells in the third to fourth passage were used throughout the experiment. For treatment of cells with homocysteine and other agents, when cells were grown close to confluence, the medium was replaced with fresh culture medium containing $10 \%$ fetal calf serum. Incubations were further continued for the indicated periods of time in the presence or absence of various concentrations of these compounds. Radiochromium release assay was performed as described previously (19).

Antithrombin III binding to endothelial cells. Antithrombin III was labeled with ${ }^{125}$ I by using Iodogen, as previously described (18). Its specific activity was $5-15 \times 10^{3} \mathrm{cpm} / \mathrm{ng}$. Specific [ $\left.{ }^{125} \mathrm{I}\right]$ antithrombin III binding to endothelial cells was determined by the method previously described (18). Briefly, $\left[{ }^{125} \mathrm{I}\right]$ antithrombin III with or without a 100 -fold excess of unlabeled protease inhibitor was placed on washed endothelial cell cultures in $0.2 \mathrm{ml}$ of Hanks' balanced salt solution at $37^{\circ} \mathrm{C}$. After rapid washes, bound [ $\left.{ }^{125} \mathrm{I}\right]$ antithrombin III was eluted by adding $1 \mathrm{ml}$ of $3 \mu \mathrm{g} / \mathrm{ml}$ heparin in RPMI 1640 medium. The radioactivity in heparin solutions, that represented reversible antithrombin III binding to the cell surface, was counted by $\gamma$ scintillation counter (Packard Instrument Co., Inc., Meriden, CT). Nonspecific binding was defined as the amount of $\left[{ }^{125} \mathrm{I}\right]$ antithrombin III bound in the presence of an excess of unlabeled protease inhibitor, and accounted for $<30 \%$ of total binding. Specific binding was obtained by subtracting nonspecific binding from total binding.

Biosynthesis and characterization of endothelial cell surface glycosaminoglycans. For metabolic labeling of glycosaminoglycans, cell cultures in $100-\mathrm{mm}$ dishes were incubated with $50 \mu \mathrm{Ci} / \mathrm{ml}$ of $\left[{ }^{35} \mathrm{~S}\right]$ sulfate usually for $24 \mathrm{~h}$ in the presence or absence of homocysteine. Labeled glycosaminoglycans were obtained from cells according to the previously described method (16) with slight modifications. Briefly, the washed cell layers were trypsinized and resultant cell suspensions were centrifuged to obtain a supernatant ("cell surface fractions"). Trypsin can effectively remove glycosaminoglycans from the cell surface and from the solubilized matrix (16). ${ }^{35} \mathrm{~S}$-labeled glycosaminoglycans were precipitated by $85 \%$ ethanol containing $1.3 \%$ potassium acetate before or after treatments with $0.5 \mathrm{IU} / \mathrm{ml}$ of chondroitin $\mathrm{ABC}$ lyase, after proteolytic digestion with pronase. Heparan sulfate was determined as chondroitin $\mathrm{ABC}$ lyase-resistant glycosaminoglycans. After incubations at $-20^{\circ} \mathrm{C}$ for $12 \mathrm{~h}$, the precipitate was collected by centrifugation at $10,000 \mathrm{~g}$ for $30 \mathrm{~min}$. These were dissolved in $0.1 \mathrm{ml}$ of water, and their radioactivities were measured by liquid scintillation counting. Protein contents in the cells were measured according to Lowry et al. (20).

The nature of radiolabeled glycosaminoglycans was analyzed by anion exchange high performance liquid chromatography on Mono Q, and that of heparan sulfate by antithrombin III affinity chromatography on Affi-Gel as previously described (18).

Detection of heparan sulfate with high-affinity for antithrombin III by dot blot assay. Cell surface heparan sulfate with high affinity for antithrombin III was also quantitated by their ability to bind radiolabeled antithrombin III, as judged by a nitrocellulose dot-blot assay described by Kojima et al. (21). Heparan sulfate from control and homocysteine-treated cells with an equal amount of ${ }^{35} \mathrm{~S}$ radioactivity was diluted in phosphate buffered saline and transferred onto nitrocellulose membranes placed in a dot-blot apparatus. The blotted membranes were then incubated with phosphate buffered saline containing
$5 \%$ nonfat milk at $22^{\circ} \mathrm{C}$ for $1 \mathrm{~h}$. $\left[{ }^{125} \mathrm{I}\right]$ Antithrombin III was added at a concentration of $1 \times 10^{6} \mathrm{cpm} / \mathrm{ml}$, and an additional incubation of $1 \mathrm{~h}$ was carried out at $22^{\circ} \mathrm{C}$. After washes, the membrane was incubated with phosphate buffered saline containing $0.8 \mathrm{M} \mathrm{NaCl}$ for $1 \mathrm{~h}$, and was then washed with phosphate buffered saline containing $5 \mathrm{mM} \mathrm{MgCl}_{2}, 5$ $\mathrm{mM} \mathrm{CaCl}$, and $5 \mu \mathrm{g} / \mathrm{ml}$ of bovine serum albumin, dried, and quantitated by autoradiography.

\section{Results}

Effects of homocysteine on endothelial cell viability. Previous studies $(19,22)$ showed that homocysteine-induced cytotoxicity occurred in proportion to the incubation time and the concentrations of both homocysteine and serum in the culture medium. The susceptibility to homocysteine also varied, depending on differences in species and vascular sites from which endothelial cells were derived. The conditions used in the present study; i.e., incubations of porcine aortic endothelial cells with $0.1-1 \mathrm{mM}$ homocysteine in the presence of $10 \%$ fetal calf serum for $\leq 24 \mathrm{~h}$, did not produce cell detachment, loss of viability determined by trypan blue dye exclusion, or any change in microscopic appearances or protein contents of the cells. In addition, no significant specific release of ${ }^{51} \mathrm{Cr}$ was observed.

Effects of homocysteine on antithrombin III binding to endothelial cell surface. Endothelial cells were grown in the absence or presence of various concentrations $(0.1,0.5$, and 1.0 $\mathrm{mM}$ ) of homocysteine for $24 \mathrm{~h}$. The binding of antithrombin III to the cell surface was assayed in parallel with the measurement of the incorporation of $\left[{ }^{35} \mathrm{~S}\right]$ sulfate into heparan sulfate in "cell surface fractions" (Fig. 1). The amount of antithrombin III specifically bound to the cell surface was progressively

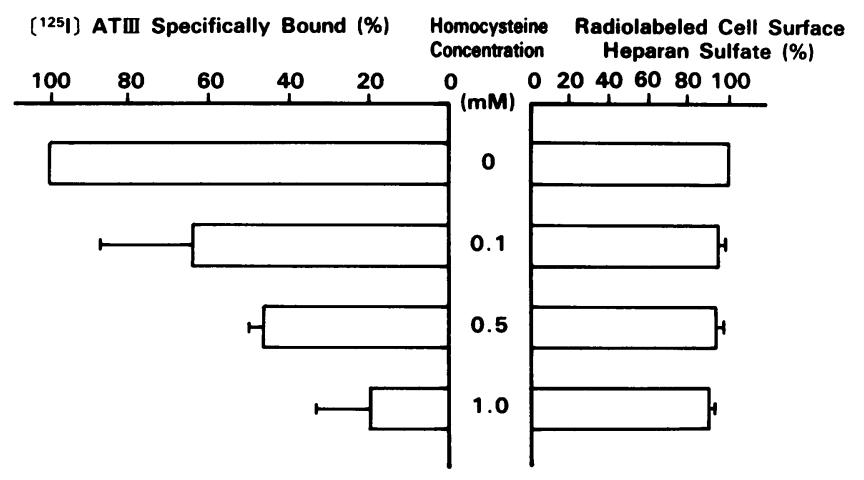

Figure 1. Effects of increasing concentrations of homocysteine on $\left[{ }^{125} \mathrm{I}\right]$ antithrombin III binding to endothelial cells and $\left[{ }^{35} \mathrm{~S}\right]$ sulfate incorporation into cell surface heparan sulfate. Endothelial cell cultures ( $256 \mu \mathrm{g}$ cell protein/dish), after treatment with various concentrations $(0,0.1,0.5$ and $1.0 \mathrm{mM})$ of homocysteine for $24 \mathrm{~h}$, were incubated with $16 \mathrm{nM}$ of $\left[{ }^{125} \mathrm{I}\right]$ antithrombin III $(A T I I I)$. [ $\left.{ }^{125} \mathrm{I}\right]-$ Antithrombin III specifically bound to the cell surface was determined as described in Methods, and is shown on the left. In parallel with these experiments, endothelial cells under identical culture conditions were labeled with [ ${ }^{35} \mathrm{~S}$ ] sulfate for $24 \mathrm{~h}$, and the radioactivity incorporated into heparan sulfate (determined as chondroitin ABC lyase-resistant materials) in "cell surface fractions" was determined as described in Methods, and is shown on the right. Results are expressed as percent of those obtained in the absence of homocysteine (111 \pm 22 $\mathrm{fmol} / \mathrm{mg}$ cell protein and $1,642 \pm 130 \mathrm{dpm} / \mu \mathrm{g}$ cell protein). Data represent the mean \pm SEM of four to six determinations. 
decreased with an increase in the concentration of homocysteine. At a concentration as low as $0.1 \mathrm{mM}$, the binding decreased by $\sim 40 \%$, and at $1 \mathrm{mM}$ of homocysteine, the binding was reduced to $\sim 20 \%$ of control. In contrast with a marked reduction in the binding, the radioactivity of $\left[{ }^{35} \mathrm{~S}\right]$ sulfate incorporated into heparan sulfate on the cell surface was not or minimally $(<15 \%)$ reduced by homocysteine treatment. Furthermore, ${ }^{35} \mathrm{~S}$-labeled glycosaminoglycans in "cell surface fractions" from control and homocysteine-treated cells accounted for $76.2 \pm 1.4$ and $76.5 \pm 0.5 \%$ of total cellular ${ }^{35} \mathrm{~S}$-labeled glycosaminoglycans respectively (mean \pm SEM of four determinations). Thus, the yield of cell surface-associated glycosaminoglycans was not affected by homocysteine treatments.

Fig. 2 shows the time course study of antithrombin III binding of the endothelial cells treated with $1 \mathrm{mM}$ of homocysteine in parallel with $\left[{ }^{35} \mathrm{~S}\right]$ sulfate incorporation into cell surface-associated heparan sulfate. Although the antithrombin III binding decreased with an increase in the incubation time $\leq 24 \mathrm{~h}$, a substantial suppression of antithrombin III binding was apparent only after $12 \mathrm{~h}$. Maximal inhibition occurred at $24 \mathrm{~h}$ of incubation. Again, little effect on the incorporation of ${ }^{35} \mathrm{~S}$ radioactivity was demonstrated throughout the time-course study.

The binding of antithrombin III to control and $1 \mathrm{mM}$ homocysteine-treated endothelial cells were measured with increasing concentrations of $\left[{ }^{125} I\right]$ antithrombin III (Fig. 3). The maximal binding of antithrombin III to the surface of homocysteine-treated endothelial cells was $\sim 30 \%$ of that in control cells.

Characterization of cell-surface heparan sulfate from homocysteine-treated endothelial cells. Anion-exchange chromatography of ${ }^{35} \mathrm{~S}$-labeled glycosaminoglycans isolated from control and $1 \mathrm{mM}$ homocysteine-treated endothelial cells demon-

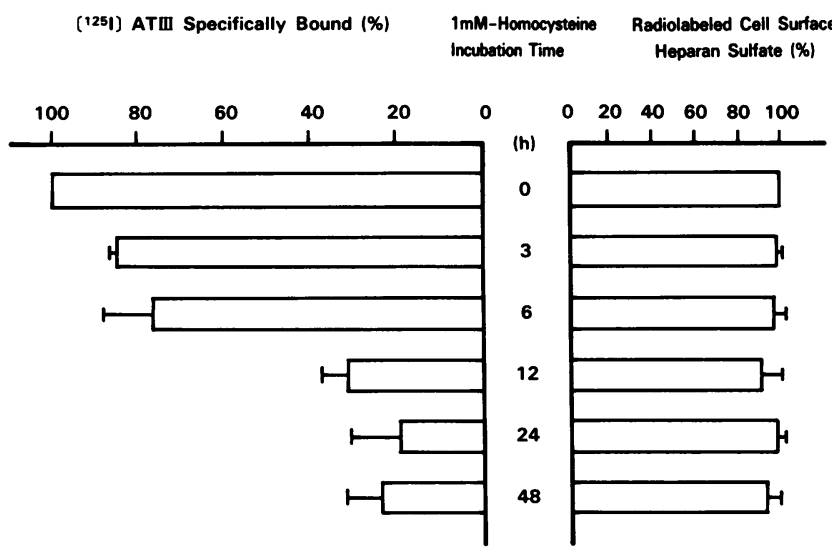

Figure 2. Effects of homocysteine on the time course of $\left[{ }^{125} \mathrm{I}\right]-$ antithrombin III binding to endothelial cells and $\left[{ }^{35} S\right]$ sulfate incorporation into cell surface heparan sulfate. Endothelial cell cultures ( $226 \mu \mathrm{g}$ cell protein/dish) grown for the indicate time periods $(0,3$, $6,12,24$ and $48 \mathrm{~h}$ ) in the presence or absence of $1 \mathrm{mM}$ homocysteine, were incubated with $16 \mathrm{nM}$ of [ $\left.{ }^{125} \mathrm{I}\right]$ antithrombin III to determine specific antithrombin III binding to the cell surface as described in Methods, and is shown on the left. In parallel with these experiments, endothelial cells under indentical culture conditions were labeled with $\left[{ }^{35} \mathrm{~S}\right]$ sulfate for 3-24 $\mathrm{h}$ before the end of the incubation period. Results are expressed as percent of those obtained in the absence of homocysteine $(106 \pm 18 \mathrm{fmol} / \mathrm{mg}$ cell protein and $1,487 \pm 258$ $\mathrm{dpm} / \mu \mathrm{g}$ cell protein $)$. Data represent the mean \pm SEM of three to four experiments.

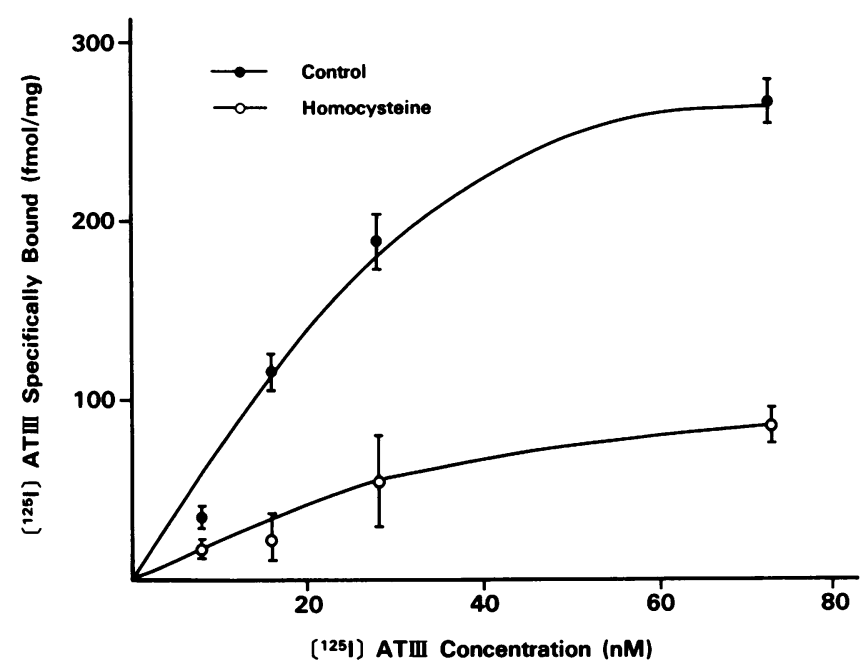

Figure 3. Specific antithrombin III binding to control and homocysteine-treated endothelial cells. Endothelial cells were incubated without (closed circle) or with $1 \mathrm{mM}$ of homocysteine (open circle) for 24 $h$. Increasing concentrations (10-75 $\mathrm{nM})$ of $\left[{ }^{125} \mathrm{I}\right]$ antithrombin III were then placed on washed endothelial cell cultures and the amount of $\left[{ }^{125} \mathrm{I}\right]$ antithrombin III specifically bound was determined as described in Methods. Data represent the mean \pm SEM of three or four determinations from two separate experiments.

strated two major peaks (Fig. 4). After chondroitin ABC lyase treatment, only an earlier larger peak was detectable, indicating that it represented heparan sulfate. Neither elution positions nor proportion of heparan sulfate $(74 \pm 4$ vs $74 \pm 8 \%$ of total ${ }^{35}$ S-glycosaminoglycans for control and homocysteine-treated endothelial cells respectively, mean \pm SEM of three separate experiments) was affected by homocysteine treatment.

The results of fractionation of ${ }^{35} \mathrm{~S}$-labeled heparan sulfate by affinity chromatography on antithrombin-Affi-Gel are shown in Fig. 5. A portion of the high affinity material that was eluted by $0.8-2 \mathrm{M} \mathrm{NaCl}$ was $61 \%$ less in homocysteine-treated cells than in control cells. The dot-blot assay produced consistent results (Fig. 6). The densitometry showed that heparan sulfate from homocysteine-treated cells revealed less [ $\left.{ }^{125} \mathrm{I}\right]-$ antithrombin III binding activity than that from control cells ( $42 \pm 3 \%$ of control, mean \pm SEM of three determinations).

Mechanisms of findings. The specificity of reduced antithrombin III binding was examined using additional sulfhydryl agents. The antithrombin III binding activity decreased after preincubation with $1 \mathrm{mM}$ homocysteine, cysteine, or 2mercaptoethanol, all of which contain free thiol groups (Fig. 7). No reduction in binding activity was observed after preincubation with the same concentration of methionine, alanine (or valine, not shown). Thus, the inhibition of antithrombin III binding to endothelial cells may be mediated by a sulfhydryl-dependent mechanism.

Further evidence for sulfhydryl-dependent reaction was provided by the addition of the free radical scavenger, catalase $(1,000 \mathrm{U} / \mathrm{ml})$ or superoxide dismutase $(200 \mathrm{U} / \mathrm{ml})$. Coincubation with catalase completely prevented the inhibition of [ ${ }^{125}$ I] antithrombin III binding to endothelial cells by homocysteine (Fig. 8), but superoxide dismutase actually tended to augment the effect of homocysteine, possibly by virture of the copper contained in the enzyme. In fact, in the presence of copper ion, inhibitory effects of homocysteine on $\left[{ }^{125} \mathrm{I}\right]-$ 

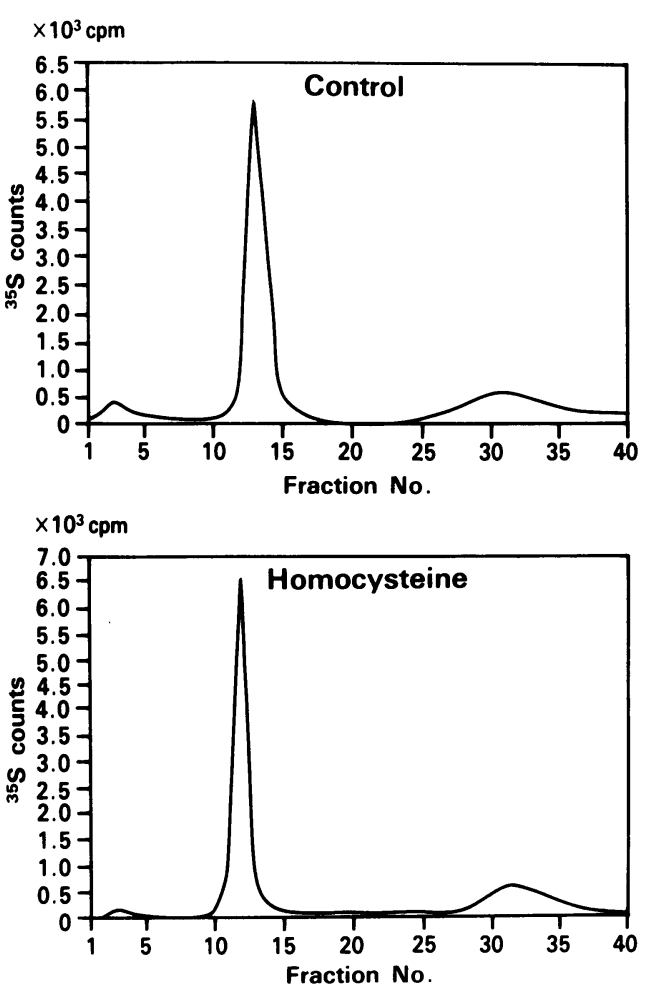

Figure 4. Characterization of ${ }^{35}$ S-labeled cell surface glycosaminoglycans from control and homocysteine treated endothelial cells. Endothelial cell cultures were incubated in culture media containing $\left[{ }^{35} \mathrm{~S}\right]-$ sulfate in the presence or absence of $1 \mathrm{mM}$ homocysteine for $24 \mathrm{~h}$. ${ }^{35} \mathrm{~S}$-labeled glycosaminoglycans isolated from "cell surface fractions" was subjected to ion-exchange chromatography on Mono $\mathrm{Q}$ as described in Methods. Column recoveries were always $>90 \%$. Experiments were repeated three times, and the variation in elution positions was $<10 \%$.

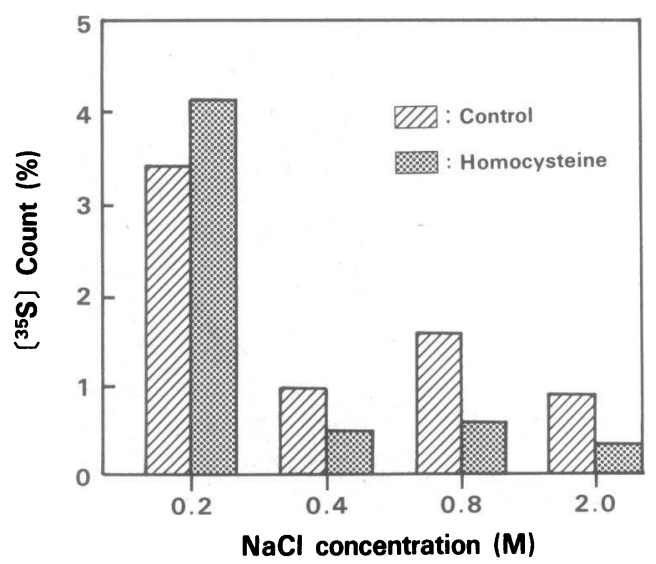

Figure 5. Fractionation of ${ }^{35} \mathrm{~S}$-labeled cell surface heparan sulfate by antithrombin-affinity chromatography. ${ }^{35} \mathrm{~S}$-labeled cell surface heparan sulfate derived from control and homocysteine-treated cells were dissolved in $0.01 \mathrm{M}$ Tris- $\mathrm{HCl}$ ( $\mathrm{pH} \mathrm{7.4),} \mathrm{applied} \mathrm{to} \mathrm{antithrombin-}$ Affi-Gel and eluted stepwise by increasing the $\mathrm{NaCl}$ concentration $(0.2,0.4,0.8$, and $2.0 \mathrm{M} \mathrm{NaCl})$ as described in Methods. Most of the radioactivity applied was unbound to the column. The fraction of $0.2 \mathrm{M} \mathrm{NaCl}$ represents nonspecifically adsorbed radioactivity. The radioactivity in each fraction is expressed by percent of the total radioactivity applied to the column. Column recovery was $>90 \%$.

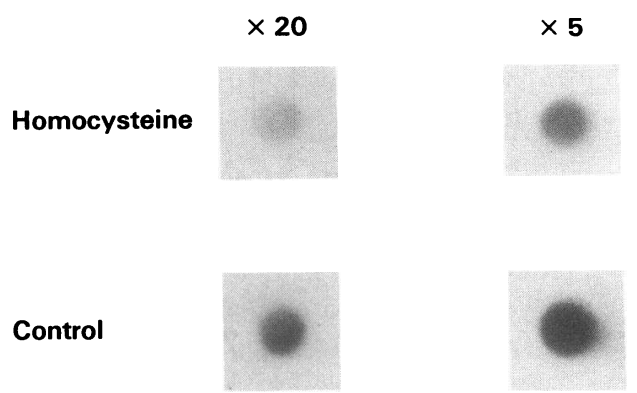

Figure 6. Dot-blot autoradiography assay of $\left[{ }^{125} \mathrm{I}\right]$ antithrombin III binding to cell surface heparan sulfate from control and homocysteine-treated endothelial cells. Heparan sulfate from control and homocysteine-treated cells with equal amounts of ${ }^{35} \mathrm{~S}$-radioactivity was diluted 5- or 20-fold in phosphate buffered saline, and transferred onto the nitrocellulose membrane placed in a dot-blot apparatus. The blotted membrane was incubated with [ ${ }^{125}$ I] antithrombin III and quantitated by autoradiography as described in Methods. No visible dots were detected in control membranes incubated without $\left[{ }^{125} \mathrm{I}\right]-$ antithrombin III.

antithrombin III binding to endothelial cells was substantially enhanced (Fig. 9). The amount of antithrombin III bound to cells treated with homocysteine at a concentration as low as 10 $\mu \mathrm{M}$ in the presence of $5 \mu \mathrm{M}$ copper sulfate for $24 \mathrm{~h}$ was reduced to $36 \%$ of control (mean of four determinations). Either homocysteine or copper alone had only minor effect on the binding ( 74 and $77 \%$ of control, respectively) at this concentration. The amount of cell surface ${ }^{35} \mathrm{~S}$-glycosaminoglycans did not change after treatments with homocysteine and copper alone or in combination.

\section{Discussion}

Previous studies showed that homocysteine decreased cell surface thrombomodulin expression and protein $\mathrm{C}$ activation, suggesting that the perturbation of the vascular endothelial cell protein $\mathrm{C}$ mechanism by homocysteine may contribute to the thrombotic tendency seen in patients with elevated blood levels of this metabolite (13-15). In the present study, we showed that homocysteine-treated endothelial cells largely lost an-

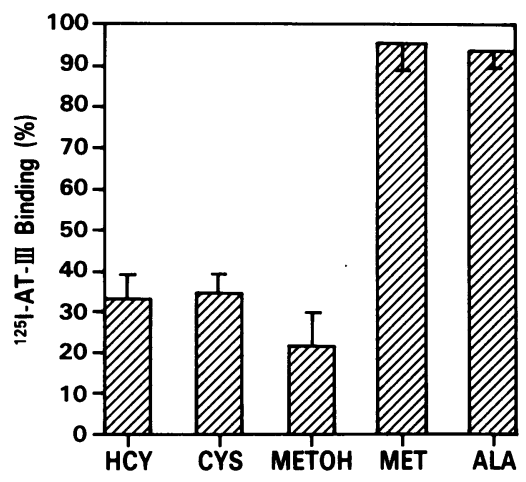

Figure 7. Effects of free thiol groups on [ $\left.{ }^{125} \mathrm{I}\right]$ antithrombin III binding to endothelial cells. Endothelial cell cultures after treatment with 1 $\mathrm{mM}$ of sulfhydryl agents, homocysteine $(H C Y)$, cysteine ( $C Y S)$, 2-mercaptoethanol $(M E T O H)$, or nonsulfhydryl agents, methionine $(M E T)$, alanine $(A L A)$ for $24 \mathrm{~h}$ were tested for $\left[{ }^{125} \mathrm{I}\right]$ antithrombin III binding. Results are expressed as percent of the amount of antithrombin III bound to control cells incubated without any agents $(95 \pm 12 \mathrm{fmol} / \mathrm{mg}$ cell protein $)$. Data represent the mean \pm SEM of three separate experiments. 


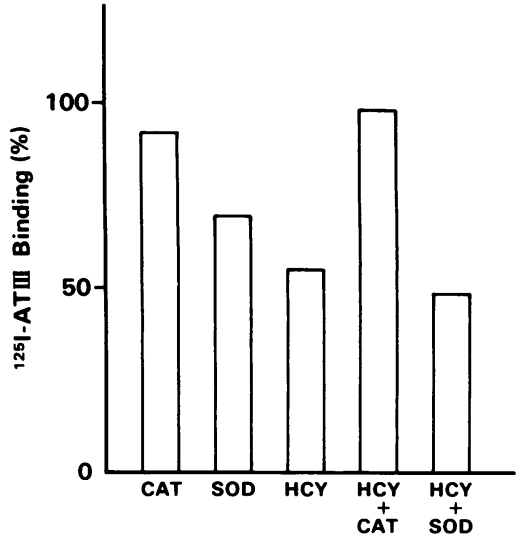

Figure 8. Effects of catalase and superoxide dismutase on homocysteine-induced inhibition of $\left[{ }^{125} \mathrm{I}\right]$ antithrombin III binding to endothelial cells. Endothelial cell cultures were incubated with $5 \mathrm{mM}$ homocysteine $(H C Y)$ in the presence or absence of catalase ( $C A T ; 1,000$ $\mathrm{U} / \mathrm{ml}$ ) or superoxide dismutase (SOD; 200 $\mathrm{U} / \mathrm{ml}$ ) for $6 \mathrm{~h}$, and tested for [ $\left.{ }^{125} \mathrm{I}\right]$ antithrombin III binding. Increased cell lysis was observed after incubation with catalase for $>6 \mathrm{~h}$. In the assay conditions as above, the cells remained viable. Results are expressed as percent of the amount of antithrombin III bound to control cells incubated without any agents $(89 \pm 9 \mathrm{fmol} / \mathrm{mg}$ cell protein). Data shown are representative of two separate experiments that differed by $<10 \%$.

tithrombin III binding activity. This did not result from either "cellular injury" or nonspecific suppression of cellular metabolism caused by cytotoxic effects of this metabolite. In fact, unlike cytokines, which reduced antithrombin III binding primarily by inhibiting endothelial glycosaminoglycan metabolism rather nonspecifically (4), the overall biosynthesis of endothelial glycosaminoglycans, as judged by both $\left[{ }^{35} \mathrm{~S}\right]$ sulfate incorporation into glycosaminoglycans, and the proportion and the net negative charge of heparan sulfate, remained almost intact. In contrast, we found a substantial reduction in antithrombin III binding capacity of heparan sulfate isolated from homocysteine-treated endothelial cells using both affinity chromatography and dot blot assay techniques. It has been shown that only a small portion (a few percent) of endothelial cell surface-associated heparan sulfate possesses a specific oligosaccharaide sequence with high affinity for antithrombin III, and is almost exclusively responsible for the binding of antithrombin III to the cells $(21,23)$. This interaction between endothelial heparin-like compounds and the protease inhibitor is believed to contribute to the anticoagulant activity of the endothelial cells $(1,24)$. Thus, we demonstrated for the first time that homocysteine specifically inhibits the expression of endothelial anticoagulant heparin-like compounds, thereby perturbing an endothelial anticoagulant mechanism mediated by the interaction with antithrombin III.

The mechanism of the synthesis and expression of anticoagulant heparan sulfate in endothelial cells is not well known. It requires the production of a core protein; assembly of a linkage region of four monosaccaride units; generation of a precursor oligosaccharide chain; and subsequent polymer-modification reactions including deacetylation of $\mathrm{N}$-acetylglucosamine residues, $N$-sulfation of the resulting free amino groups, conversion of D-glucuronic acid to L-iduronic acid units by epimerization at C-5, $O$-sulfation at $\mathrm{C}-2$ of iduronic acid units, and $O$ sulfation at C- 6 of glucosamine units. The final step of this complex remodeling process is thought to be the glucosamine3-O-sulfotransferase reaction resulting in the generation of a region of a unique sequence of sulfated and nonsulfated uronic acid and glucosamine residues, which are required to complex with the protease inhibitor $(25,26)$. Homocysteine appears to perturb this biosynthetic pathway in rather a specific way, and diminish cell-surface expression of anticoagulant heparan sulfate with high affinity for antithrombin III, without gross alterations of overall cellular glycosaminoglycan biosynthesis. The mechanism by which cells treated with the metabolite are defective in the synthesis and/or subsequent expression on the cell surface of heparan sulfate with the unique monosaccharide sequence required for the binding of antithrombin III remains to be determined. The synthesis of specific core proteins for anticoagulantly active heparan sulfate (21), if any, or the multimolecular arrays of biosynthetic enzymes that carry out posttranslational modifications of the oligosaccaride chains within the Golgi complex might be perturbed by homocysteine. The latter concept is in accord with the recent study (14), which showed that in the presence of homocysteine, incorporation of $\left[{ }^{35} \mathrm{~S}\right]$ sulfate into chondroitin sulfate glycosaminoglycan associated with thrombomodulin decreased, suggesting that at least one of the direct or indirect target sites of homocysteine-induced perturbation could be a cytoplasmic process of proteins and/or proteoglycans within the Golgi complex. A future investigation of the detailed molecular basis of the defective anticoagulant heparan sulfate expression in homocysteine-treated cells should help us to understand how cells synthesize and express heparan sulfate proteoglycans with regions of defined monosaccharide sequence (26).

The inhibition of antithrombin III binding to the cells required free thiol groups. Hence, the mechanism by which homocysteine inhibits anticoagulant heparan sulfate appeared to relate to redox potential of the sulfhydryl-containing agent. This sulfhydryl effect may be caused by generation of hydrogen peroxide during thiol autoxidation (25-27), as incubation of catalase, but not superoxide dismutase, with homocysteinetreated endothelial cells prevented this response. In addition, the effect of homocysteine was enhanced in the presence of

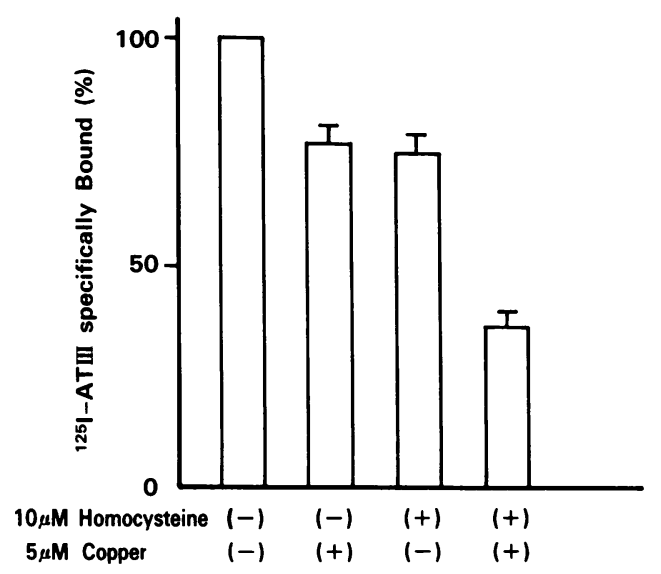

Figure 9. Effects of copper $\left(\mathrm{CuSO}_{4}\right)$ on homocysteine-induced inhibition of $\left[{ }^{125} \mathrm{I}\right]$ antithrombin III binding to the endothelial cells. Endothelial cell cultures were incubated with $10 \mu \mathrm{M}$ homocysteine in the presence or absence of $5 \mu \mathrm{M}$ copper $\left(\mathrm{CuSO}_{4}\right)$ for $24 \mathrm{~h}$ and tested for $\left[{ }^{125} I\right]$ antithrombin III binding. In these assay conditions, the cells remained viable. Results are expressed as percent of the amount of antithrombin III bound to control cells incubated without any agents $(90 \pm 7 \mathrm{fmol} / \mathrm{mg}$ cell protein $)$. Data shown are the mean $\pm \mathrm{SEM}$ of four determinations. 
copper ion. This may be accounted for by copper-catalyzed hydrogen peroxide generation (22). These results are consistent with the previous reports which showed that homocysteine and other sulfhydryl agents could cause endothelial cell injury via hydrogen peroxide generation, as manifested by cell detachments or ${ }^{51} \mathrm{Cr}$ release $(19,22,27,28)$. It should be emphasized, however, that the inhibition of antithrombin III binding by homocysteine occurred without apparent "cellular injury", and that this effect was evident only after no less than $6 \mathrm{~h}$ of incubation in the present study, suggesting that hydrogen peroxide generation primarily may have affected biosynthetic processes of anticoagulant heparan sulfate in endothelial cells, but not directly "injured" those already present on the cell surface. On the other hand, it has been shown that homocysteine-induced suppression of protein $\mathrm{C}$ activation by endothelial cells is more rapid; i.e., $>50 \%$ reduction within $0.5-3 \mathrm{~h}(13,15)$, and that sulfhydryl groups may $(14)$ or may not $(13,15)$ be required for this effect. The role of hydrogen peroxide was not evident in one of those studies (13). Instead, homocysteine may directly inhibit the thrombomodulin cofactor activity by reducing the disulfide-bond structures of the protein, with an increase in thrombomodulin mRNA and thrombomodulin protein synthesis as a compensatory mechanism $(13,15)$. Thus, homocysteine might inhibit two major anticoagulant pathways in endothelial cells by different mechanisms.

The inhibitory effect of homocysteine occurred at an $\sim 10$ fold less concentration of the metabolite in the present study than that used in the previous experiments (13-15) $(0.1-1$ $\mathrm{mM}$ vs $1-10 \mathrm{mM}$, respectively). Plasma concentrations of free homocysteine present in homocystinuric patients are reported to be less than $1 \mathrm{mM}(12)$, while levels of homocysteine found in plasma of patients with premature vascular disease are considerably lower than those in homozygous homocysteinemic patients; e.g., 10-30 $\mu \mathrm{M}$ of homocysteine (7-10). Our data showing the inhibited expression of antithrombin III-mediated anticoagulant system in endothelial cells by homocysteine concentration as low as $0.1 \mathrm{mM}$, or even at as lower concentration as $10 \mu \mathrm{M}$ in some conditions affecting redox potential; e.g., in the presence of copper ion, may be pathophysiologically relevant, at least in certain clinical situations. Furthermore, the inhibited expression of anticoagulant heparan sulfate may be a highly sensitive marker of "endothelial cell perturbation" subsequent to alteration of the redox potential.

\section{Acknowledgments}

This work was supported in part by research grants 4454270 from the Ministry of Education, Science, and Culture, and 2A-1 for Cardiovascular Disease from the Ministry of Health and Welfare in Japan. We are greatful to Ms. Hisada, Ms. Nakazawa, and Ms. Kanbe for their expert technical assistances.

\section{References}

1. Rosenberg, R. D., and J. S. Rosenberg. 1984. Natural anticoagulant mechanisms. J. Clin. Invest. 74:1-6.

2. Nawroth, P. P., D. A. Handley, C. T. Esmon, and D. M. Stern. 1986. Interleukin 1 induces endothelial cell procoagulant while suppressing cell-surface anticoagulant activity. Proc. Natl. Acad. Sci. USA. 83:3460-3464.
3. Esmon, C. T. 1987. The regulation of natural anticoagulant pathways. Science (Wash. DC). 235:1348-1352.

4. Kobayashi, M., K. Shimada, and T. Ozawa. 1990. Human recombinant interleukin $1 \beta$-and tumor necrosis factor $\alpha$-mediated suppression of heparin-like compounds on cultured porcine aortic endothelial cells. J. Cell. Physiol. 144:383-390.

5. Esmon, C. T. 1992. The protein C anticoagulant pathway. Arterioscler. Thromb. 12:135-145.

6. Mudd, S. H., F. S. Skovby, H. L. Levy, K. D. Pettigrew, B. Wilcken, R. E. Pyeritz, G. Andria, G. H. J. Boers, I. L. Bromberg, R. Cerone, et al. 1985. The natural history of homocystinuria due to cystathionine $\beta$-synthase deficiency. Am. J. Hum. Genet. 37:1-31.

7. Clarke, R., L. Daly, K. Robinson, E. Naughten, S. Cahalane, B. Fowler, and I. Graham. 1991. Hyperhomocysteinemia: an independent risk factor for vascular disease. N. Engl. J. Med. 324:1149-1155.

8. Stampfer, M. J., M. R. Malinow, W. C. Willett, L. M. Newcomer, B. Upson, D. Ullmann, P. V. Tishler, and C. H. Henneckens. 1992. A prospective study of plasma homocyst(e)ine and risk of myocardial infarction in US physicians. J. Am. Med. Assoc. 268:877-881.

9. Malinow, M. R. 1990. Hyperhomocyst(e)inemia. A common and easily reversible risk factor for occlusive atherosclerosis. Circulation. 81:2004-2006.

10. Harker, L. A., S. J. Slichter, C. R. Scott, and R. Ross. 1974. Homocystinemia. Vascular injury and arterial thrombosis. N. Engl. J. Med. 291:537-543.

11. Harker, L. A., R. Ross, S. J. Slichter, and C. R. Scott. 1976. Homocystineinduced arteriosclerosis. The role of endothelial cell injury and platelet response in its genesis. J. Clin. Invest. 58:731-741.

12. Rodgers, G. M., and W. H. Kane. 1986. Activation of endogenous factor $\mathrm{V}$ by a homocysteine-induced vascular endothelial cell activator. J. Clin. Invest. 77:1909-1916.

13. Rodgers, G. M., and M. T. Conn. 1990. Homocysteine, an atherogenic stimulus, reduces protein $\mathrm{C}$ activation by arterial and venous endothelial cells. Blood. 75:895-901.

14. Lentz, S. R., and J. E. Sadler. 1991. Inhibition of thrombomodulin surface expression and protein $\mathrm{C}$ activation by the thrombogenic agent homocysteine. $J$. Clin. Invest. 88:1906-1914.

15. Hayashi, T., G. Honda, and K. Suzuki. 1992. An atherogenic stimulus homocysteine inhibits cofactor activity of thrombomodulin and enhances thrombomodulin expression in human umbilical vein endothelial cells. Blood. 79:2930-2936.

16. Shimada, K., and T. Ozawa. 1985. Evidence that cell surface heparan sulfate is involved in the high affinity thrombin binding to cultured porcine aortic endothelial cells. J. Clin. Invest. 75:1308-1316.

17. Shimada, K., A. Kawamoto, K. Matsubayashi, and T. Ozawa. 1989. Histidine-rich glycoprotein does not interfere with interactions between antithrombin III and heparin-like compounds on vascular endothelial cells. Blood. 73:191-193.

18. Shimada, K., and T. Ozawa. 1987. Modulation of glycosaminoglycan production and antithrombin III binding by cultured aortic endothelial cells treated with 4-methylumbelliferyl- $\beta$-D-xyloside. Arteriosclerosis. 7:627-636.

19. Wall, R. T., J. M. Harlan, L. A. Harker, and G. E. Striker. 1980. Homocysteine-induced endothelial cell injury in vitro: a model for the study of vascular injury. Thromb. Res. 18:113-121.

20. Lowry, O. H., N. J. Rosebrough, A. L. Farr, and R. J. Randall. 1951. Protein measurement with the folin phenol reagent. J. Biol. Chem. 193:265-275.

21. Kojima, T., C. W. Leone, G. A. Marchildon, J. A. Marcum, and R. D. Rosenberg. 1992. Isolation and characterization of heparan sulfate proteoglycans produced by cloned rat microvascular endothelial cells. J. Biol. Chem. 267:48594869.

22. Starkebaum, G., and J. M. Harlan. 1986. Endothelial cell injury due to copper-catalyzed hydrogen peroxide generation from homocysteine. J. Clin. Invest. 77:1370-1376.

23. Marcum, J. A., D. H. Atha, L. M. S. Fritze, P. Nawroth, D. Stern, and R. D. Rosenberg. 1986. Cloned bovine aortic endothelial cells synthesize anticoagulantly active heparan sulfate proteoglycan. J. Biol. Chem. 261:7507-7517.

24. Wight, T. N. 1989. Vessel proteoglycans and thrombogenesis. Prog. Hemostasis Thromb. 5:1-39.

25. Lindahl, U. L. F., M. Kusche, K. Lidholt, and L. G. Oscarsson. 1989. Biosynthesis of heparin and heparan sulfate. Ann. NY Acad. Sci. 556:36-59.

26. de Agostini, A. L., H. K. Lau, C. Leone, and H. Youssoufian. 1990. Cell mutants defective in synthesizing a heparan sulfate proteoglycan with regions of defined monosaccharide sequence. Proc. Natl. Acad. Sci. USA. 87:9784-9788.

27. Saez, G., P. J. Thornalley, H. A. O. Hill, R. Hems, and J. V. Bannister. 1982. The production of free radicals during the autoxidation of cysteine and their effect on isolated rat hepatocytes. Biochim. Biophys. Acta. 719:24-31.

28. Dudman, N. P. B., C. Hicks, J. Wang, and D. E. L. Wilcken. 1991. Human arterial endothelial cell detachment in vitro: its promotion by homocysteine and cysteine. Atherosclerosis. 91:77-83. 